\title{
Mahasiswa dan Peradaban Pemikiran
}

\section{Students and Civilizations of Thought}

\author{
Budi Ali Mukmin Sarumpaet * dan Nurhairani \\ Jurusan Pendidikan Pancasila dan Kewarganegaraan, Fakultas Ilmu Sosial \\ Jurusan Pendidikan Guru Sekolah Dasar, Fakultas Ilmu Pendidikan \\ Univesitas Negeri Medan, Indonesia
}

\begin{abstract}
Abstrak
Mahasiswa merupakan bagian yang tidak dapat dipisahkan bagi maju dan berkembangnya sebuah peradaban pemikiran suatu bangsa. Mahasiswa harus menjadi penular virus dalam perubahan sosial agar mahasiswa tidak memiliki jarak dengan masyarakat. Disinilah mahasiswa dituntut untuk memiliki komitmen besar untuk terlibat dalam sebuah perubahan dan bukan sebagai sok jagoan dengan berbagai teori perubahan. Yang diperlukan para intelektual mahasiswa saat ini adalah menjadikan ilmu dan pengaetahuannya untuk merekonstruksi sekaligus mendekonstruksi ulang berbagai macam ide pemikiran yang tidak hanya dinikmati secara individual namun dapat dipertanggungjawabkan secara moral sehingga berdampak terhadap pola fikir dan pola perilaku yang positif bagi masyarakat. Pemikiran transformative merupakan tujuan akhir dimana peradaban pemikiran yang riel adalah meletakkan ilmu pengetahuan pada tujuan prinsip dasarnya dimana ilmu pengetahuan tidak lagi mencari "untuk apa itu " atau "untuk apa ini” tetapi bagaimana ilmu pengetahuan mampu menerjemahkan bagaimana seharusnya ilmu pengetahuan berdampak riel untuk menyelesaikan masalah yang ada di dalam kehidupan berbangsa dan bernegara.

Keyword: Mahasiswa, Peradaban Pemikiran, Pemikiran Transformative.
\end{abstract}

\begin{abstract}
Students are an inseparable part for the advancement and development of a civilization of the thinking of a nation. Students must become virus transmitters in social change so that students do not have a distance with the community. This is where students are required to have a great commitment to engage in a change and not as pretentious with various theories of change. What is needed by the intellectuals of students today is to make the knowledge and knowledge to reconstruct and redecorate various ideas of ideas that are not only enjoyed individually but can be held morally accountable so as to affect the pattern of fikir and positive behavior patterns for the community. Transformative thinking is the ultimate goal in which the realization of the civilization of thought is to put science on the goal of its basic principle in which science no longer seeks "for what it is" or "for what it is" but how science is able to translate how science should have a real impact to solve problems that exist in the life of nation and state.
\end{abstract}

Keyword: Students, Civilization of Thought, Transformative Thinking

How to Cite: Sarumpaet, B.A.M., dan Nurhairani, (2017). Mahasiswa dan Peradaban Pemikiran. JPPUMA: Jurnal Ilmu Pemerintahan dan Sosial Politik UMA, 5 (2): 79-84

\begin{tabular}{lr}
\hline${ }^{*}$ Corresponding author: & p-ISSN: 25491660 \\
E-mail: bamsarumpaet@gmail.com & e-ISSN: 2550-1305
\end{tabular}




\section{PENDAHULUAN}

"Dasar berdirinya universitas ialah bahwa ia mengadakan jembatan antara pengetahuan dan sari penghidupan, dengan menyatukan yang muda dan yang tua di dalam pandangan imaginatif yang mencipta tentang belajar, dan universitas memberikan petunjuk, tetapi petunjuk disertai dengan ciptaan" Mohammad Hatta, 1957

Kutipan kalimat di atas merupakan potongan kecil dari pidato Muhammad Hatta dengan tema Tanggung Jawab Moral Kaum Inteligensia yang beliau sampaikan pada pertemuan alumni mahasiswa UI (Universitas Indonesia) pada tahun 1957. Bagi Hatta, universitas harus menjadi tempat pendidikan manusia yang bertanggung jawab terhadap masyarakat dan universitas juga sebagai wadah untuk melahirkan para pemimpin sekaligus para pekerja yang bertanggungjawab di dalam kehidupan masyarakat. Dalam pidato itu juga, Hatta kerap melekatkan kalimat "masyarakat" sebagai fase akhir tujuan berdirinya universitas. Sangat penting untuk kita berfikir sekaligus menyematkan sebuah pertanyaan, mengapa kalimat "masyarakat" menjadi tujuan akhirnya.

Tulisan ini tidak berkeinginan membahas secara detail tentang pidato Muhammad Hatta. Hanya saja, tulisan ini sangat terinspirasi dari pidato tersebut yang nantinya akan dikaitkan dengan kondisi saat ini dimana universitas begitu banyak mengorbitkan mahasiswa pada tiap tahunnya namun tidak menunjukkan dimana khittah mahasiswa itu sesungguhnya. Bagi penulis, universitas tidak hanya melahirkan para pemimpin dan para pekerja semata, melainkan universitas juga bertanggungg jawab melahirkan banyak pemikiran yang bermuara pada munculnya sebuah peradaban yang terbarukan bagi setiap generasinya.

Pada konteks ini pula, "peradaban atau civilization" tidak diarahkan pada sebuah kemajuan yang dibayangkan oleh Spingler dimana peradaban merupakan sebuah kebudayaan yang telah mencapai taraf yang tinggi ataupun kompleks. (Spingler, 1927: 136). Pada konteks ini, peradaban akan dibatasi pada output kebermanfaatan ilmu pengetahuan kepada masyarakat. Dengan bahasa yang sederhana, "peradaban pemikiran" dimaksudkan bagaimana universitas sebagai wadah bagi mahasiswa atau para intelektual untuk merekonstruksi sekaligus mendekonstruksi ulang berbagai macam ide pemikiran yang tidak hanya dinikmati secara individual namun dapat dipertanggungjawabkan secara moral sehingga berdampak terhadap pola fikir dan pola perilaku yang positif bagi masyarakat.

\section{PEMBAHASAN}

Bangsa Indonesia pernah melahirkan para intelektual yang memiliki pengaruh luar biasa dalam menularkan virus gagasan yang dapat membangkitkan gairah dan semangat pembangunan bangsa ini. Soekarno merupakan bentuk nyata bagaimana konsep Marhein-nya begitu banyak mendapatkan dukungan dari masyarakat bahkan menjadi soroton dunia. Pun demikian dengan Hatta dan Syahrir, intelektual yang pernah menularkan gagasan sosialisme pada sebuah gagasan kongkrit yang bernama "Demokrasi Ekonomi". Sama halnya dengan Tan Malaka yang disejajarkan oleh George Mc.T Kahin sebanding dengan Ho Chi Minh dalam hal gagasan komunismenya. Dikalangan intelektual Islam, bangsa Indonesia memiliki beberapa tokoh seperti HOS Cokroaminoto, Buya Hamka maupun Muhammad Natsir dll, yang meletakkan gagasan pemikiran Islam dalam politik Indonesia. Bahkan untuk Natsir seorang Indonesianis Geogre Mc.T Kahin juga mendapuknya dengan julukan salah legenda besar dalam peletakan Indonesia Modern dengan mengedepankan jalurjalur demokrasi ala Indonesia untuk mendapatkan kekuasaan (Zed, 2010: 87) dan beliau juga dikenal sebagai Integrator NKRI dengan konsep toleransinya dalam bernegara (Feisal. 2016: 163) meskipun 
beliau pernah mengalami masa-masa kelam dalam perjuangan politiknya.

Secara umum, daya magis pemikiran beberapa tokoh di atas menimbulkan akses kebermanfaatan luar biasa bagi pembangunan bangsa Indonesia saat ini. Menurut hemat penulis mereka layak menyandang peletak peradaban pemikiran Indonesia, karena mereka menjadikan nilai-nilai budaya yang ada dalam negara ini sebagai perangkat dasar untuk berfikir kemudian diterjemahkan kedalam perilaku bernegara.

Sungguh tak layak bila penulis membandingkan kelemahan dan kelebihan antar lintas generasi dalam mengembangkan gagasan dan pemikiran yang berkembang di Indonesia. Namun, ada baiknya kita melihat benang merah dimana terputusnya peradaban pemikiran Indonesia yang sempat berjaya pada masanya.

Pertama adalah pada masa Orde Lama. Lahirnya peradaban pemikiran kaum intelektual terdahulu dapat dikatakan sebagai bentuk perlawanan dari penindasan dari praktik kolonialisme. Meminjam istilah yang digunakan oleh Hatta (Hatta. 1984: 24) bahwa para intelegensia terdahulu lebih terfokus merubuhkan pemikiran-pemikiran dari Hindia Belanda yang dirasa tidak sesuai dengan pembangunan bangsa Indonesia sekaligus berkeinginan untuk melepaskan belenggu penjajahan.

Gagasan Hatta tentang "Demokrasi Indonesia” (Suleman. 2010: 181) merupakan bentuk kongkrit bagaimana ia menentang gagasan demokrasi yang diimport dari dunia barat. Hatta cukup piawai untuk meyakinkan masyarakat Indonesia dengan pemikirannya yang mengatakan bahwa indiviudalisme demokrasi yang digagas dunia barat sangat bertentangan dengan kondisi riil bangsa Indonesia. Hatta justru menilai bahwa demokrasi Indonesia harus disesuaikan dengan sosiologis rakyat Indonesia yang suka tolong menolong dan suka gotong royong. Gagasan inilah cikal bakal lahirnya demokrasi ekonomi bernama "Koperasi" yang mengedepankan semangat solidaritas sesama anggotanya untuk mencapai keuntungan bersama dan bermuara kepada kedaulatan ekonomi. Dalam demokrasi bidang politik Hatta juga memperkenalkan bangsa ini pada konsep demokrasi yang mengedepankan konsep musyawarah yang menolak keras adanya sikap individualisme yang tidak terkontrol. (Noer, 1990: 494)

Singkatnya, pada masa ini titik fokus peradaban pemikiran di awali dari pengambangan ilmu pengetahuan bersumber dari nilai-nilai kultural yang ada di negara ini. Nilai-nilai tersebut kemudian dijadikan sebuah konsep berfikir dengan tujuan mulia yakni menuju sebuah kedaulatan bangsa yang ingin melepaskan dari bayang-bayang penjajahan. Universitas sebagai sumber ilmu menjadi jembatan yang baik bagi mahasiswa untuk melakukan berbagai penyelidikan pengetahuan dengan mulai menalar, berfikir dan bertindak sesuai dengan kaidah ke-ilmuan untuk menuju satu tujuan yakni Indonesia berdaulat (meliputi kedaulatan politik, kedaulatan ekonomi, kedaulatan energi, kedaulatan pangan, serta kedaulatan pengetahuan).

Kedua, Pada masa Orde Baru peradaban pemikiran yang berkembang di Indonesia mengalami pergeseran orientasi baik dari segi ke-ilmuan maupun orientasi praktisnya. La trabision des clercs (penghianatan kaum intelektual) merupakan label yang dilekat Harry J Benda untuk melihat para intelektual pada masa Orde Baru yang telah menyesuaikan diri kepada berbagai macam aliran egois dan berbagai kepentingan, dipungut dan disewa oleh pihak yang berkuasa sehingga mahasiswa sebagai embrio intelektual telah keluar dari fungsinya (Hatta. 1984: 22)

Tidak bisa dipungkiri bahwa kekuasaan otoriter rezim Orde Baru memberikan dampak langsung mundurnya daya magis pemikiranpemikiran yang telah lama berkembang, bahkan beberapa pemikiran yang dapat membangun daya kritis mahasiswa justru dibredel dengan dalih stabilitas keamanan. 
Institusi ataupun lembaga ilmu pengetahuan justru menjadi alat pembenaran bagi rezim Orde Baru untuk bertindak. Orde Baru mulai merekonstruksi lembanga-lembaga ilmu pengetahuan termasuk institusi kampus menjadi sebuah lembaga yang hanya memproduksi pasar tenaga kerja dan sebagai penunjuk langkah-langkah kerja pemerintah.

Pada masa Orde Baru paradaban pemikiran justru terkonsentrasi pada satu tujuan yakni "pembangunan" yang menjadi hantu bagi krisis ilmu pengetahuan (Dakidae. 2003: 355), khusususnya Ilmu Pengetahuan Sosial. Indikator pembangunan hanya dilihat dengan grafik dan hitungan angka-angka yang menakjubkan tanpa memikirkan dampak-dampak sosial dari pembangunan. Tak ayal bila pemikiranpemikiran sosial yang muncul pada saat itu hanya pemikiran berbentuk kritikan terhadap rejim Orde Baru. Praktis ruang gerak Ilmu Sosial hanya terwadahi dengan buliten/majalah yang bernama Prisma dan tidak ada lagi ruang selain itu. Inilah yang disebut oleh Harry J Benda bahwa pergerakan kaum intelegensia dikawasan timur menjalin mesra dengan kekuasaan sehingga para intelektual menjadi elit politik yang mendapatkan segepok kekuasaan dan melakukan monopoli terhadap kekuasaan politik tersebut (Benda, 1984: 126).

Mahasiswa sebagai front terdepan lahirnya peradaban pemikiran juga absen untuk untuk menghiasi khazanah pengembangan ilmu pengetahuan. Pada periode ini pula lah, peradaban pemikiran di Indonesia dibanjiri oleh pemikirpemikir dari barat yang memiliki label Indonesianis. Herbert Feith, Geogre Mc.T Kahin, Cliffort Geertz, Ben Anderson, William Liddle, Ruth Mc Avey, adalah beberapa Indonesianis yang menjejali pengetahuan tentang bangsa ini. Kita memang harus berterimakasih kepada mereka yang terlebih dahulu melakukan riset-riset di negara ini, namun tidak bisa dipungkiri mereka jugalah yang berjasa terhadap pengkotak-kotakan ilmu pengetahuan khususnya dalam bidang ilmu sosial, ekonomi dan ilmu politik.

Universitaspun tampaknya mengaminkan hasil-hasil riset yang dikembangkan kalangan Indonesianis dan menjadikan riset tersebut menjadi rujukan utama. Sayangnya, mahasiswa pada periode ini justru hanya menjadi penikmat karya-karya mereka dan bukan untuk menjadikan riset tersebut membangun sebuah karya pemikiran yang mandiri dan bersifat utuh.

Ketiga, lengsernya rezim Orde Baru tidak serta merta memutus mandegnya peradaban pemikiran di Indonesia. Mahasiswa memang berjasa untuk menggulingkan rezim otoriter dengan aksi heroik pada tahun 1998. Sayangnya social movement yang digalang mahasiswa bersifat tentative melalui hubungan mesra dengan elit-elit politik yang terpinggirkan pada masa Orde Baru. Praktis perjuangan mahasiswa masih terlihat pada pola pergerakan massa dan bukan pada pola pergerakan dan pembangunan peradaban pemikiran bagaimana membangun Indonesia. Argumentasi ini bukanlah bersifat final dan tentunya masih terbuka untuk diperdebatkan.

Periode ini juga berjasa melabelkan mahasiswa dengan sebutan kaum reformis. Sekali lagi, kaum reformis yang berasal dari kalangan kampus tak mampu untuk melepaskan hubungan terlarang dengan elit-elit politik yang kembali naik tahta. Kaum reformis terbawa eforia dengan keberhasilan tahun 1998 bahkan terlanjur latah untuk menikmati hingga menduduki tampuk-tampuk kekuasaan dengan gelar politisi.

Salah satu dampak positif imbas dari reformasi dalam pengembangan keilmuan adalah universitas mulai menata kembali khittah jati dirinya. Universitas mulai mencari jalan keluar untuk mengatasi mandegnya gagasan pemikiran yang telah lama terputus dengan cara mulai menyediakan berbagai saluran dan fasilitas bagi setiap para pendidik (dosen) dan 
mahasiswa untuk mengembangkan gagasan dan pemikirannya.

Sayangnya, penyediaan berbagai fasilitas teknologi yang diberikan universitas tak mampu dimanfaaatkan dengan bijak baik dosen maupun mahasiswa sebagai calon kaum intelektual. Lihat lah, bagaimana karya-karya yang dihasil mahasiswa baik berupa Skripsi (S1), Thesis (S-2), dan Disertasi $\left(\mathrm{S}_{3}\right)$ nyaris tidak berkontribusi untuk menyelesaikan persoalaan-persoalan pelik bangsa. Jika persoalan bangsa dianggap terlalu besar, minimal karya tesebut berkonstribusi nyata pada bagian lokalitas objek kajian penelitiannya.

Tulisan ini tidak menawarkan segudang solusi yang dapat menciptakan sebuah peradaban pemikiran yang cepat, dan terkesan sok-pintar untuk mengajak seluruh kaum intelektual yang membaca artikel ini secara cepat untuk merubah kerangka berfikirnya. Pemikiran transformatif merupakan konsep yang ingin dikenalkan dalam tulisan ini, meskipun kerangka dasar pemikiran ini belum begitu lazim untuk diaplikasikan karena pemikiran ini membutuhkan sebuah komitmen dan energi besar untuk terlibat secara langsung dalam proses perubahan sosial.

Peletakan kalimat pemikiran transformatif ini diilhami guru saya sendiri Purwo Santoso yang tertuang dalam pidato pengukuhan guru besar Ilmu Politik Universitas Gadjah Mada Yogyakarta. Menurut beliau, pemikiran transformatif lahir dari aktivitas pengembangan ilmu yang dilakukan dalam kesehariannya akan berkonstribusi bagi penanganan masalah bangsa dan kebangsaan (Santoso, 2011: 5). Beliau sebenarnya hendak menggugah serta menyentil sistem pendidikan yang ada saat ini, dimana pendidikan hanya menghasilkan orang-orang pandai mendiskripsikan banyak permasalahan dan mencari kesalahan, dari pada orangorang yang efektif mengarahkan dan turut andil dalam mengusung sebuah perubahan sosial (Santoso, 2011: 5). Yang menjadi pertanyaan kita selanjutnya adalah bagaimana menjadikan pemikiran transformatif menjadi sebuah peradaban pemikiran? dan dimana posisi mahasiswa untuk mengkreasikan pemikiran trasformatif tersebut.

Menjadikan pemikiran transformatif menuju sebuah peradaban pemikiran bukanlah hal yang mustahil untuk dilakukan. Bahkan, sudah selayaknya berbagai macam ilmu pengetahuan harus dituntut berkonstribusi untuk menangani berbagai macam persoalaan kebangsaan. Paling tidak ada tiga langkah yang harus kita perkenalkan untuk mendudukkan kerang berfikir yang transpormatif. Pertama, universitas sebagai lembaga pendidikan yang menggodok ide-ide besar harus duduk bersama dengan dosen dan mahasiswa untuk meletakkan model ataupun gaya pembelajaran seperti apa yang tepat untuk terlibat langsung dalam perubahan-perubahah sosial. Dalam hal ini proses pembelajaran tidak lagi bersumber pada persoalaan menjawab apa, dimana salahnya dan bagaimana teorinya. Pembelajaran justru akan di awali dengan sebuah problem masalah apa yang muncul dalam kehidupan sehari-hari. Kedua, universitas, dosen beserta mahasiswa tampaknya harus memiliki tujuan yang sama dimana ruang keterlibatan mereka dalam proses perubahan sosial. Ketiga, pengembangan keilmuan seperti apa yang tepat untuk menyelesaikan permasalahan yang ada sehingga dari pengembangan keilmuan tersebut sifatnya melekat dan menjadi sebuah budaya yang ajeg dalam berfikir maupun dalam bertindak bagi setiap individunya (Santoso, 2011: 5).

Meletakkan mahasiswa sebagai penular virus dalam perubahan sosial merupakan salah satu jalan agar mahasiswa tidak memiliki jarak dengan masyarakat. Disinilah mahasiswa dituntut untuk memiliki komitmen besar untuk terlibat dalam sebuah perubahan dan bukan sebagai sok jagoan dengan berbagai teori perubahan. Dalam tulisan ini ijinkanlah saya mencotohkan bagaimana agenda ini sedang berjalan di Jurusan 
PPKn Unimed yang telah bergabung dengan 7 Universitas di pulau Jawa dengan sebuah gerakan DEEP NETWORK. DEEP NETWORK merupakan sebuah wadah yang diinisiasi oleh Prof. Purwo Santoso di Yogyakarta pada tahun 2016. Adapun Universitas yang tergabung dalam wadah ini adalah UGM Yogyakarta, Universitas Muhammadiyah Yogyakarta, Universitas Sunan Kalijaga Yogyakarta, Universitas Islam Indonesia Yogyakarta, Universitas Negeri Surabaya, Universitas Negeri Semarang dan Universitas Negeri Medan.

\section{SIMPULAN}

Inti dari artikel ini adalah menuju "Kewarganegaraan Transpormatif" dimana mahasiswa lintas universitas digabungkan dalam sebuah forum daring yang diberinama MOOC (Massive Open Online Course). Dalam forum ini masing-masing mahasiswa bisa saling berinteraksi dengan tema yang bersentuhan langsung dengan kehidupan masyarakat sehari-hari. Tagihan yang diminta dalam forum ini adalah kontribusi apa yang dapat dilakukan mahasiswa untuk menyelesaikan masalah yang kemudian dikemas dalam bentuk video, dianalisis bersama-sama dimana pada akhirnya akan dijadikan kerangka berfikir untuk terlibat dalam sebuah perubahan sosial.

Sekali lagi, pola fikir transformatif ini memang membutuhkan komitmen dan ketangguhan bagi setiap individunya. Di Jurusan Pendidikan Pancasila dan Kewarganegaraan pun, kegiatan masih banyak menghadapi rintangan, terutama pada bagian komitmen dan kesedaran kolektif untuk terlibat dalam sebuah proses perubahan itu sendiri.

$\begin{array}{lr}\text { Yang diperlukan para intelektual } \\ \text { untuk menjadikan } & \text { pemikiran } \\ \text { transformatif menjadi } & \text { sebuah }\end{array}$
peradaban pemikiran yang riel adalah meletakkan ilmu pengetahuan pada tujuan prinsip dasarnya dimana ilmu pengetahuan tidak lagi mencari "untuk apa itu " atau "untuk apa ini" tetapi bagaimana ilmu pengetahuan mampu menerjemahkan bagaimana seharusnya ilmu pengetahuan berdampak riel untuk menyelesaikan masalah yang ada. Meminjam istilah yang digunakan Hatta, sejatinya universitas yang melahirkan intelektual (mahasiswa) membentuk manusia susila dan demokratis yang mempunyai keinsafan tanggung jawab atas kesejahteraan masyarakat Indonesia. (Hatta, 1984: 7)

\section{DAFTAR PUSTAKA}

Benda, J.H., (1984), "Kaum Intelegensia Timur sebagai Golongan Elit Politik" dalam buku Cendikiawan dan Politik. $\mathrm{LP}_{3} \mathrm{ES}$. Jakart.

Dakidae, D., (2003). Cendikiawan Kekuasaan dalam Negara Orde Baru. Gramedia Pustaka. Jakarta.

Feisal, A.H.J. (2008). "Mohammad Natsir Sebagai Integrator NKRI" dalam buku 100 tahun Mohammad Natsir Berdamai dengan Sejarah. Republika. Jakarta.

Hatta, M. (1984). "Tanggung Jawab Moral Kaum Intelegensia" dalam buku Cendikiawan dan Politik. LP3ES. Jakarta. Hal 24.

Noer, D., (1990). Mohammad Hatta Biografi Politik. $\mathrm{LP}_{3}$ ES. Jakarta.

Santoso, P. (2011). "Penguatan Jati Diri dan Karakter Bangsa Melalui Pendidikan Ilmu Sosial Transformatif", dalam pidato Dies Natalis ke-46 Fakultas Ilmu Sosial dan Ekonomi Universitas Negeri Yogyakarta.

Suharyanto, A., Armansyah M., Taufik W.H., (2016), Aktualisasi dan Filosofi Konsep Kepemimpian Tradisional Bagi Generasi Muda di Bale Marojahan Medan, Jurnal Pendidikan Ilmu-Ilmu Sosial, 8 (2) (2016): 182-189

Suleman, Z. (2010). Demokrasi Untuk Indonesia. Kompas Gramedia. Jakarta.

Spingler, O. (1927). The Decline of The West Civilization. Albert. A Knopf. Inc. New York.

Zed, M. (2008). "Mohammad Natsir, Negarawan, Pemikir Islam Dalam Pembentukan Indonesia Modern" dalam 1oo tahun Mohammad Natsir Berdamai dengan Sejarah. Republika. Jakarta. 